\title{
Akt2- and ETS1-Dependent IP3 Receptor 2 Expression in Dendritic Cell Migration
}

\author{
Wenting Yang ${ }^{a}$ Meerim K. Nurbaeva ${ }^{a}$ Evi Schmid ${ }^{a}$ Antonella Russo ${ }^{a}$ \\ Ahmad Almilajia Kalina Szteyn ${ }^{a}$ Jing Yan ${ }^{a}$ Caterina Faggio ${ }^{b} \quad$ Ekaterina Shumilina ${ }^{a, c}$ \\ Florian Lang ${ }^{a, c}$ \\ aDepartment of Physiology, University of Tübingen, Tübingen, Germany; ${ }^{b}$ Department of Biological and \\ Environmental Sciences, University of Messina, S.Agata-Messina, Italy; ${ }^{c}$ contributed equally and thus \\ share senior authorship
}

\author{
Key Words \\ $\mathrm{CCL} 21 \cdot \mathrm{Ca}^{2+}$ release $\cdot \mathrm{I}_{\mathrm{CRAC}} \cdot \mathrm{SOCE}$
}

\begin{abstract}
Background/Aims: The protein kinase Akt2/PKB $\beta$ is a known regulator of macrophage and dendritic cell (DC) migration. The mechanisms linking Akt2 activity to migration remained, however, elusive. DC migration is governed by $\mathrm{Ca}^{2+}$ signaling. We thus explored whether Akt2 regulates $\mathrm{DC} \mathrm{Ca}{ }^{2+}$ signaling. Methods: DCs were derived from bone marrow of Akt2deficient mice $\left(a k t 2^{-/}\right)$and their wild type littermates $\left(a k t 2^{+/+}\right)$. DC maturation was induced by lipopolysaccharides (LPS) and evaluated by flow cytometry. Cytosolic $\mathrm{Ca}^{2+}$ concentration was determined by Fura-2 fluorescence, channel activity by whole cell recording, transcript levels by RT-PCR, migration utilizing transwells. Results: Upon maturation, chemokine CCL21 stimulated migration of $a k t 2^{+/+}$but not akt2 ${ }^{-/} \mathrm{DCs}$. CCL21-induced increase in cytosolic $\mathrm{Ca}^{2+}$ concentration, thapsigargin-induced release of $\mathrm{Ca}^{2+}$ from intracellular stores with subsequent store-operated $\mathrm{Ca}^{2+}$ entry (SOCE), ATP-induced inositol 1,4,5-trisphosphate $\left(\mathrm{IP}_{3}\right)$-dependent $\mathrm{Ca}^{2+}$ release as well as $\mathrm{Ca}^{2+}$ release-activated $\mathrm{Ca}^{2+}(\mathrm{CRAC})$ channel activity were all significantly lower in mature akt2-/ than in mature $a k t 2^{+/+} \mathrm{DCs}$. Transcript levels of $\mathrm{IP}_{3}$ receptor $\mathrm{IP}_{3} \mathrm{R} 2$ and of $\mathrm{IP}_{3} \mathrm{R} 2$ regulating transcription factor ETS1 were significantly higher in $a k t 2^{+/+}$than in $a k t 2^{-/-}$ DCs prior to maturation and were upregulated by LPS stimulation (1h) in $a k t 2^{+/+}$and to a lower extent in $a k t 2^{-/-}$DCs. Following maturation, protein abundance of IP $R 2$ and ETS1 were similarly higher in $a k t 2^{+/+}$than in $a k t 2^{-/-} \mathrm{DCs}$. The $\mathrm{IP}_{3} \mathrm{R}$ inhibitor Xestospongin $\mathrm{C}$ significantly decreased CCL21-induced migration of $a k t 2^{+/+} \mathrm{DCs}$ and abrogated the differences between genotypes. Finally, knock-down of ETS1 with siRNA decreased IP ${ }_{3}$ R2 mRNA abundance, thapsigargin- and ATP-induced $\mathrm{Ca}^{2+}$ release, SOCE and CRAC channel activation, as well as DC migration. Conclusion: Akt2 upregulates DC migration at least in part by ETS1-dependent stimulation of $\mathrm{IP}_{3} \mathrm{R} 2$ transcription.


Yang et al.: Akt2- and ETS1-Sensitive $\mathrm{IP}_{3} \mathrm{R} 2$

\section{Introduction}

Migration of dendritic cells (DCs) is of utmost importance for the induction of both protective immunity as well as immunological tolerance. Upon stimulation with pathogenderived antigens or endogenously generated "danger" molecules, activated DCs acquire a migratory phenotype associated with the upregulation of the chemokine receptor CCR7 [1]. The G protein-coupled receptor CCR7 is the dominant mediator of DC mobilization to the T cell compartment of lymphoid organs [1, 2]. CCR7 engagement by the chemokines CCL19 or CCL21 leads to the activation of phospholipase C $\beta$ (PLC $\beta$ ) [1] (Fig. 8), which hydrolyzes phosphatidylinositol 4,5-biphosphate ( $\mathrm{PIP}_{2}$ ) to generate inositol 1,4,5-trisphosphate $\left(\mathrm{IP}_{3}\right)$ and diacylglycerol (DAG). $\mathrm{IP}_{3}$ triggers $\mathrm{Ca}^{2+}$ release from intracellular stores via $\mathrm{IP}_{3}$ receptors $\left(\mathrm{IP}_{3} \mathrm{Rs}\right.$ ) in the endoplasmatic reticulum (ER). Depletion of $\mathrm{Ca}^{2+}$ in ER results in the activation of $\mathrm{Ca}^{2+}$ release-activated $\mathrm{Ca}^{2+}$ (CRAC) channels leading to a massive entry of extracellular $\mathrm{Ca}^{2+}$ [3] (Fig. 8). Blocking of CRAC channels impairs CCR7-dependent migration of DCs [4, 5]. In mouse DCs the predominant components of CRAC channels include the pore-forming subunit Orai1 and Orai 2 and the $\mathrm{Ca}^{2+}$-sensing subunit STIM1 and STIM2 [6].

CCR ligation and the resulting release of $\beta \gamma$ subunit from the activated G protein also leads to the activation of phosphatidylinositol 3' kinase (PI3K) and downstream Akt/PKB [1] (Fig. 8). Akt is known to play a pivotal role in regulating chemotaxis in leukocytes, including DCs [1]. Of the three Akt isoforms, only Akt1 and Akt2 are expressed in DCs [7]. Whereas the major function of Akt1 seems to be regulating DC survival and maturation [8], Akt2 has been shown to be pivotal for migration of DCs and macrophages $[7,9,10]$. Thus, plasmin-triggered chemotactic response of human monocyte-derived DCs [7], as well as colony-stimulating factor-1 (CSF-1)- or monocyte chemoattractant protein-1 (MCP-1)-induced chemotaxis of mouse peritoneal macrophages [9] is Akt2-dependent. We have previously shown that CCR7dependent migration is impaired in Akt2-deficient bone marrow-derived mouse DCs [10].

The mechanisms linking Akt2 activity to DC motility remained elusive. In macrophages Akt2 functions upstream of PKCろ/LIMK/cofilin directly regulating CSF-1-induced actin polymerization [9]. In epithelial cells, Akt2 has been shown to upregulate migration by modulating the transcription of genes required for migration [11]. Since DC migration is extremely sensitive to cytosolic concentrations of free $\mathrm{Ca}^{2+}\left(\left[\mathrm{Ca}^{2+}\right]_{\mathrm{i}}\right)[3]$, Akt2 may influence DC migration via regulating components of $\mathrm{Ca}^{2+}$ signaling. In lymphocytes engagement of $\mathrm{T}$ or B cell receptors leads to the activation of PI3K, which upregulates $\mathrm{Ca}^{2+}$ mobilization [1215]. Accordingly, inhibition of PI3K impairs the rise in cytosolic $\mathrm{Ca}^{2+}$ concentration upon $\mathrm{T}$ or $\mathrm{B}$ cell receptor ligation [12-15]. Moreover, another downstream target of PI3K, the serum and glucocorticoid inducible kinase SGK1, which shares 55\% identity with Akt in their kinase domain regions [16], is a powerful regulator of CRAC channels [17-21]. The present study explored the mechanisms of Akt2-dependent migration and a possible involvement of Akt2 in the regulation of $\mathrm{Ca}^{2+}$ signaling in mouse DCs. We show that in mouse dendritic cells, Akt2 enhances migration through up-regulating the expression of $\mathrm{IP}_{3} \mathrm{R} 2$ via the Akt2-dependent transcription factor ETS1, which results in an increased release of $\mathrm{Ca}^{2+}$ from intracellular stores, store-operated $\mathrm{Ca}^{2+}$ entry, and current through $\mathrm{Ca}^{2+}$ release-activated $\mathrm{Ca}^{2+}$ (CRAC) channels.

\section{Materials and Methods}

Mice and Cells

All animal experiments were conducted according to the German law for the welfare of animals and were approved by local authorities. Akt2-deficient mice (akt2\%) and their wild type littermates (akt2 $\left.{ }^{+/+}\right)$ were used in the present study. Origin of the mice, breeding and genotyping were described previously [22]. Male and female mice were studied at the age of 6-8 weeks.

Dendritic cells (DCs) were isolated from mouse bone marrow as described previously [4, 5]. Bone marrow derived cells were flushed out of the cavities from the femur and tibia with PBS. Cells were then 
Yang et al.: Akt2- and ETS1-Sensitive $\mathrm{IP}_{3} \mathrm{R} 2$

washed twice with RPMI and seeded out at a density of $2 \times 10^{6}$ cells per $60 \mathrm{~mm}$ dish. Cells were cultured for up to 9 days in RPMI 1640 (GIBCO, Carlsbad) containing: 10\% FCS, 1\% (vol/vol) penicillin/streptomycin (100x, PAA), 2 mM glutamine, 1\% (vol/vol) non-essential amino acids (MEM NEAA, 100x, Gibco) and 0.05\% $\beta$-mercaptoethanol. $\beta$-mercaptoethanol was added to the medium since it is a potent reducing agent often used in mouse (but not human) cell culture medium to prevent toxic levels of oxygen radicals [23].

Cultures were supplemented with GM-CSF $(35 \mathrm{ng} / \mathrm{mL}$, Immunotools) and fed with fresh medium containing GM-CSF on days 3 and 6. Experiments were performed on days 7-9. DC maturation was induced by treating the cells with lipopolysaccharides (LPS from E. coli, $1 \mu \mathrm{g} / \mathrm{ml}, 24 \mathrm{~h}$, Enzo Life Sciences, Lausen, Switzerland).

\section{Immunostaining and flow cytometry}

Cells $\left(10^{6}\right)$ were incubated in $200 \mu \mathrm{l} \mathrm{PBS}$, containing $0.1 \% \mathrm{FCS}$ and fluorochrome-conjugated antibodies at a concentration of $10 \mu \mathrm{g} / \mathrm{ml}$. A total of $5 \times 10^{4}$ cells were analyzed in each individual experiment. The following antibodies (all from BD Pharmingen, Heidelberg, Germany) were used for staining: Allophycocyanin (APC) Hamster Anti-Mouse CD11c (Clone: HL3), phycoerythrin (PE)-conjugated anti-mouse CD86, clone GL1 (Rat IgG $\mathrm{Ia}^{\prime} \mathrm{K}$ ) and PE-conjugated rat anti-mouse I-A/I-E, clone M5/114.15.2 (IgG2b, $\mathrm{k}$ ), which reacts with the mouse major histocompatibility complex (MHC) class II I-A/I-E molecules. Following incubation with the respective antibodies for $60 \mathrm{~min}$ at $4^{\circ} \mathrm{C}$, cells were washed twice and resuspended in the same buffer and subjected to flow cytometry analysis. For MHC II expression only the cells with high expression, which form a clear subpopulation on FACS diagrams, were analyzed (MHC ${ }^{\text {high }}$ ).

\section{Gene silencing}

Specific siRNA sequences for ETS1 (Santa Cruz), negative control (Control siRNA, Santa Cruz) were synthesized and annealed by the manufacturer. siRNA transfection was carried out using the GeneSilencer siRNA transfection reagent (Genlantis, San Diego, CA,USA). $4 \times 10^{6}$ cells were washed and plated in 6-well plates in $2 \mathrm{ml}$ of serum-free RPMI 1640. The ETS1-siRNA and the negative control siRNA ( $1 \mu \mathrm{g} / \mathrm{ml})$ were incubated with GeneSilencer reagent following the manufacturer's protocol. Transfection mixture was then added to the wells and incubated 48 hours. The efficacy of silencing was assessed with RT-PCR and western blotting.

\section{Cytokine Production}

IL-6 and IL-12 concentrations in culture supernatants from DCs treated with LPS $(1 \mu \mathrm{g} / \mathrm{ml}, 24 \mathrm{~h})$ were determined by using OptEIA ELISA kits (BD Pharmingen) according to the manufacturer's protocol.

\section{Migration}

For migration assays the transwells were placed in a 24-well cell culture plate containing cell culture medium $(750 \mu \mathrm{l})$ with or without either CXCL12 $(50 \mathrm{ng} / \mathrm{ml}$, Peprotech, for immature DCs) or CCL21 (25 $\mathrm{ng} / \mathrm{ml}$, Peprotech, for mature DCs) in the lower chamber. The upper chambers were filled with $500 \mu \mathrm{l}$ cell culture medium containing immature or LPS $(1 \mu \mathrm{g} / \mathrm{ml}, 24 \mathrm{~h})$ - matured DCs either untreated or treated with $\mathrm{IP}_{3} \mathrm{R}$ inhibitor Xestospongin C ( $5 \mu \mathrm{M}$, Enzo Life Sciences, Lausen, Switzerland) for $3 \mathrm{~h}$ in a concentration of 1 $\mathrm{x} 10^{5} \mathrm{cells} / \mathrm{ml}$, allowed to migrate through a polycarbonate mesh (pore size $8 \mu \mathrm{m}$ ) at $37^{\circ} \mathrm{C}$ for $3 \mathrm{~h}$.The cells migrated to the other side of the transwell were stained with DAPI, cells from five representative areas of each membrane were counted.

\section{Measurement of intracellular $\mathrm{Ca}^{2+}$}

To determine cytosolic $\mathrm{Ca}^{2+}$ concentration, the cells were loaded with Fura-2/AM $(2 \mu \mathrm{M}$, Molecular Probes, Goettingen, Germany) for $15 \mathrm{~min}$ at $37^{\circ} \mathrm{C}$. Fluorescence measurements were made with an inverted phase-contrast microscope (Axiovert 100, Zeiss, Oberkochen, Germany) [6]. Cells were excited alternatively at $\lambda=340$ (filter $340 / 26$ ) or 380 (filter $387 / 11$ ) $\mathrm{nm}$ and the light was deflected by a dichroic mirror into either the objective (Fluar 40×/1.30 oil, Zeiss, Oberkochen, Germany) or a camera (Proxitronic, Bensheim, Germany). Emitted fluorescence intensity was recorded at $\lambda=505$ (filter 495/10) $\mathrm{nm}$ and data acquisition was accomplished by using specialized computer software (Metafluor, Universal Imaging, Downingtown, USA). As a measure for the increase of cytosolic $\mathrm{Ca}^{2+}$ concentration, the slope and peak of the changes in the $340 / 380 \mathrm{~nm}$ ratio were determined for each experiment. 
Intracellular $\mathrm{Ca}^{2+}$ was measured prior to and following addition of CXCL12 (300 ng/ml) or CCL21 (75 $\mathrm{ng} / \mathrm{ml}$ ) to the Ringer solution (see below). Alternatively, the $\mathrm{Ca}^{2+}$ release was measured following addition of MgATP $\left(100 \mu, \mathrm{mol} / \mathrm{l}\right.$, Alfa Aesar GmbH \& Co KG, Germany) to the $\mathrm{Ca}^{2+}$-free solution (see below). In order to measure SOC entry, changes in cytosolic $\mathrm{Ca}^{2+}$ were monitored upon depletion of the intracellular $\mathrm{Ca}^{2+}$ stores. Experiments were carried out prior to and during exposure of the cells to the $\mathrm{Ca}^{2+}$-free solution. In the absence of $\mathrm{Ca}^{2+}$, the intracellular $\mathrm{Ca}^{2+}$ stores were depleted by inhibition of the vesicular $\mathrm{Ca}^{2+}$ pump by thapsigargin ( $1 \mu \mathrm{M}$, Molecular Probes). Re-addition of $\mathrm{Ca}^{2+}$ allowed assessing the store-operated $\mathrm{Ca}^{2+}$ entry.

The Ringer solution contained (in mmol/l): $125 \mathrm{NaCl}, 5 \mathrm{KCl}, 1.2 \mathrm{MgSO}_{4}, 32.2 \mathrm{Hepes}, 2 \mathrm{Na}_{2} \mathrm{HPO}_{4}, 2 \mathrm{CaCl}_{2^{\prime}}$ and 5 glucose at $\mathrm{pH}$ 7.4. The $\mathrm{Ca}^{2+}$-free solution contained (in mmol/l): $125 \mathrm{NaCl}, 5 \mathrm{KCl}, 1.2 \mathrm{MgSO}_{4^{\prime}} 2 \mathrm{Na}_{2} \mathrm{HPO}_{4^{\prime}}$ 32.2 Hepes, 0.5 EGTA, 5 glucose, $\mathrm{pH} 7.4(\mathrm{NaOH})$.

\section{Whole-cell patch clamp}

Patch clamp experiments were performed at room temperature in voltage clamp, fast-whole-cell mode according to Hamill et al. [24] as described in [4]. The currents were recorded by an EPC-9 amplifier (Heka, Lambrecht, Germany) using Pulse software (Heka) and an ITC-16 Interface (Instrutech, Port Washington, N.Y., USA).

For $\mathrm{I}_{\text {CRAC }}$ measurements whole-cell currents were elicited by $200 \mathrm{~ms}$ square wave voltage pulses from -50 to $+50 \mathrm{mV}$ in $10 \mathrm{mV}$ steps delivered from a holding potential of $-30 \mathrm{mV}$. Alternatively, the currents were recorded with $200 \mathrm{~ms}$ voltage ramps from -50 to $+50 \mathrm{mV}$. Leak currents determined as the currents at the very beginning of each experiment immediately after reaching the whole-cell mode were subtracted. The currents were recorded with an acquisition frequency of $10 \mathrm{kHz}$ and $3 \mathrm{kHz}$ low-pass filtered.

DCs were superfused with a bath solution containing (in mmol/l): $140 \mathrm{NaCl}, 5 \mathrm{KCl}, 10 \mathrm{CaCl}_{2}, 20$ glucose, $10 \mathrm{HEPES} / \mathrm{NaOH}, \mathrm{pH}$ 7.4. The patch clamp pipettes were filled with an internal solution containing (in mmol/l): $120 \mathrm{CsCl}, 35 \mathrm{NaCl}, 10$ EGTA, $10 \mathrm{HEPES} / \mathrm{CsOH}, 0.04$ inositol 1,4,5-trisphosphate (Ins(1,4,5)P ${ }_{3}$, Enzo Life Sciences), pH 7.4.

The liquid junction potential $\Delta \mathrm{E}$ between the $\mathrm{CsCl}$-based pipette and the $\mathrm{NaCl}$-based bath solutions estimated according to Barry and Lynch [25] was $1 \mathrm{mV}$. The data were not corrected for $\Delta \mathrm{E}$.

\section{Real-time PCR}

Total RNA was extracted from mouse DCs in TriFast (Peqlab, Erlangen, Germany) according to the manufacturer's instructions as described in [6].

For amplification the following primers were used (5`>> ${ }^{`}$ orientation): for $\mathrm{IP}_{3} \mathrm{R} 1$ : fw AAG CGG ATG GAC CTG GTG TTA GAA CTG and rev AAT TTG TGC TGT GTG CTT CGC GTA GAA CT; for IP $_{3}$ R2: fw CTG TTC TTC TTC ATC GTC ATC ATC ATC G and rev GAA ACC AGT CCA AAT TCT TCT CCG TGA; for IP ${ }_{3}$ R3: fw CTT CTT TAT CGT CAT CAT CAT CGT GTT G and rev AGG TTC TTG TTC TTG ATC ATC TGA GCC A; for RyR1: fw TGG GGC ACT ACA ATA ACT TC and rev AGC AGA ATG ACG ATA ACG AA; for ETS1: fw GAT ATC CTG TGG GAG CAT CTA GAG ATC and rev CAG CTG GAT CGG CCC ACT TCC TGT GTA G; for Tbp:fw CAC TCC TGC CAC ACC AGC TT and rev TGG TCT TTA GGT CAA GTT TAC AGC C.

Specificity of PCR products was confirmed by analysis of a melting curve. Real-time PCR amplifications were performed on a CFX96 Real-Time System (Bio-Rad) and all experiments were done in duplicate. The house-keeping gene Tbp (TATA binding protein) was amplified to standardize the amount of sample RNA. Relative quantification of gene expression was achieved using the $\Delta \mathrm{CT}$ method as described earlier [26].

\section{Western Blot and Immunoprecipitation}

Proteins were separated on SDS-PAGE gels and transferred to nitrocellulose membrane. After blocking in $10 \%$ nonfat dried milk in Tris-buffered saline solution (TBS-T, pH 7.4) with $0.01 \%$ Tween-20, blots were incubated with primary antibodies as follows: $\mathrm{IP}_{3} \mathrm{R} 2$ ( Santa Cruz), ETS1 (Abcam), rabbit monoclonal GAPDH (Cell Signaling, USA). Membranes were washed in TBS-T with 0.01\% Tween-20 and incubated with HRP-coupled anti-rabbit (Cell Signalling) or anti-goat (Santa Cruz) secondary antibody and washed again in TBS-T. For detection, membrane was blotted with ECL reagent (GE Healthcare), exposed to X-ray film (GE Healthcare) and developed.

Cell lysates were immunoprecipitated by using Phospho-Akt Substrate (RXRXXS*/T) antibody covalently bound protein A/G PLUS agarose beads (Santa Cruz), size-fractionated by SDS-PAGE, and immunoblotted. 


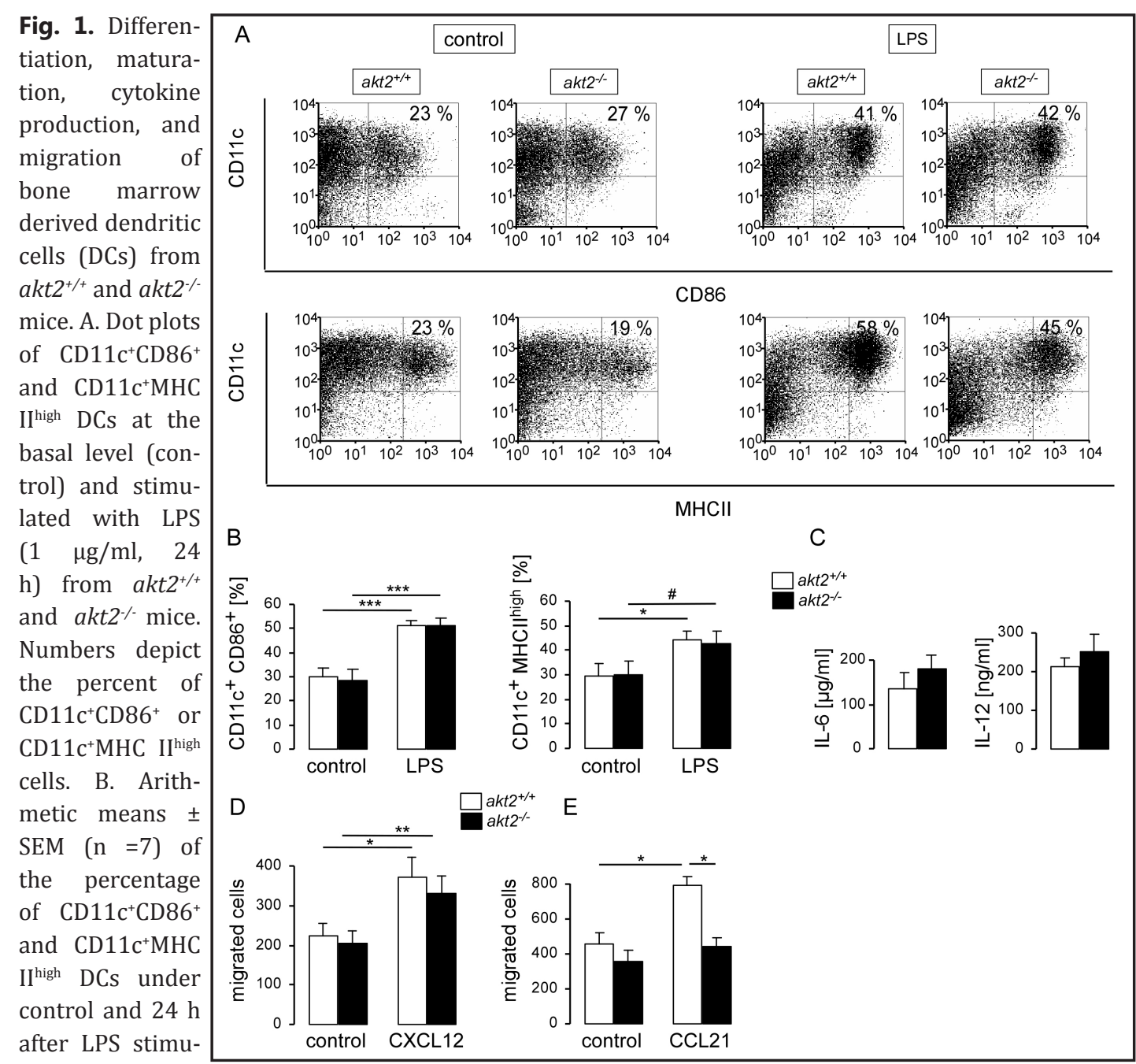

lation in $a k t 2^{+/+}$and akt2\% DCs. * $(\mathrm{p}<0.05),{ }^{* * *}(\mathrm{p}<0.001)$, ANOVA; \# $(\mathrm{p}<0.05)$, only with unpaired $t$-test. C. Arithmetic means \pm SEM ( $\mathrm{n}=8$ ) of IL-6 and IL-12 secretion in LPS $(1 \mu \mathrm{g} / \mathrm{ml}, 24 \mathrm{~h})$-stimulated $a k t 2^{+/+}$and akt2\% DCs. D.-E. Arithmetic means \pm SEM ( $\mathrm{n}=11-18)$ of spontaneous migration and migration in response to either CXCL12 (50 ng/ml, 3h, immature DCs, D) or CCL21 (25 ng/ml, 3h, LPS (1 $\mu \mathrm{g} / \mathrm{ml}, 24 \mathrm{~h})$-matured DCs, E) of $a k t 2^{+/+}$and $a k t 2 \%$ DCs. ${ }^{*}(\mathrm{p}<0.05),{ }^{* *}(\mathrm{p}<0.01)$, ANOVA.

\section{Statistics}

Data are provided as means $\pm \mathrm{SEM}, n$ represents the number of independent experiments. Differences were tested for significance using Student's unpaired two-tailed $t$-test or ANOVA. $P<0.05$ was considered statistically significant.

\section{Results}

Differentiation and maturation of dendritic cells is unaffected by Akt2 deficiency

DCs were isolated from gene targeted mice lacking functional Akt2 $(a k t 2 \%)$ and their wild type littermates $\left(a k t 2^{+/+}\right)$. As illustrated in Fig 1, the surface abundance of both, the costimulatory molecule CD86 and antigen-presenting molecule MHC II, was similar on

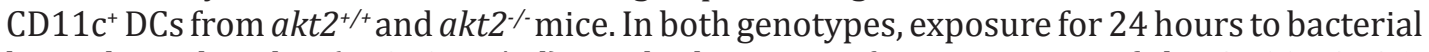
lipopolysaccharides (LPS, $1 \mu \mathrm{g} / \mathrm{ml}$ ) resulted in a significant increase of the CD11 $\mathrm{c}^{+} \mathrm{CD} 86^{+}$ population and CD11 $\mathrm{c}^{+} \mathrm{MHC}$ II $^{\text {high }}$ cells (with a high expression of MHC II). Following LPS 
Fig. 2. Diminished CCL21-induced increase of intracellular $\mathrm{Ca}^{2+}$ concentration in akt2\% DCs. A. Representative tracing showing the Fura-2 fluorescence ratios (340/380 $\mathrm{nm})$ in LPS $(1 \mu \mathrm{g} / \mathrm{ml})$ matured $a k t 2^{+/+}$DCs and $a k t 2 \%$ DCs upon acute addition of CCL21 (75 ng/ml). B. Mean ( \pm SEM) of peak and slope of the change in Fura-2 fluorescence following addition of CCL21 (75 ng/ $\mathrm{ml})$ to mature $a k t 2^{+/+}(\mathrm{n}=50)$ and $a k t 2 \%(\mathrm{n}=40)$ DCs. $^{* *}(\mathrm{p}<0.01)$, unpaired $t$-test.

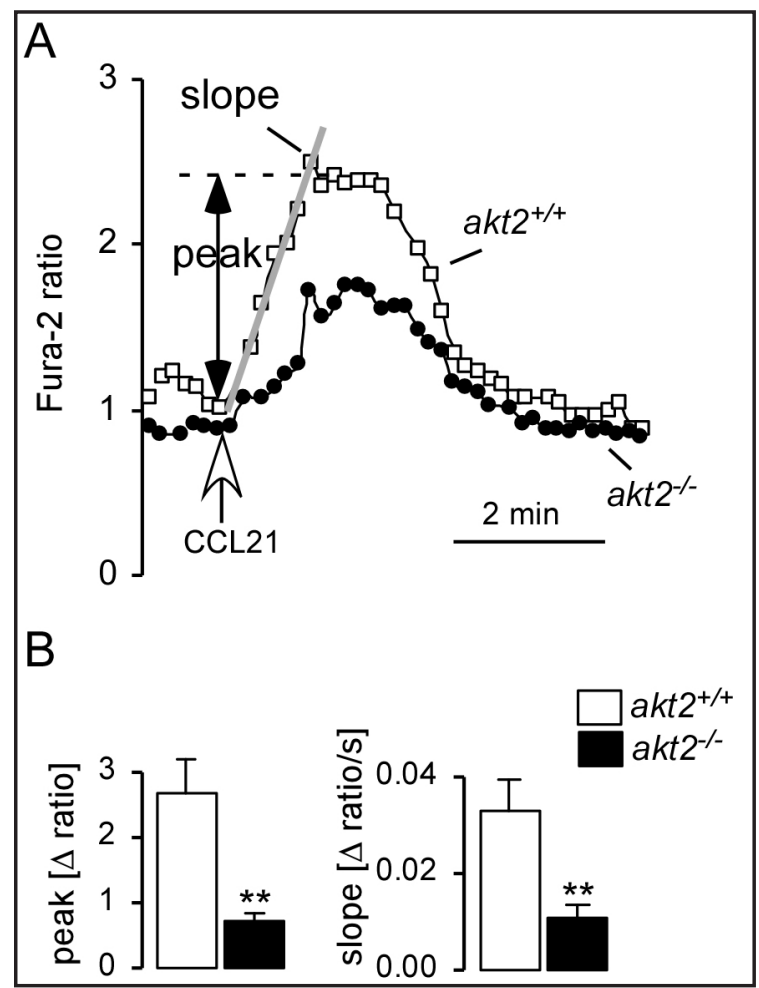

treatment, the abundance of CD86 and MHC II was still similar in DCs from $a k t 2^{+/+}$and akt2\% mice (Fig. 1A,B). The release of interleukin 6 (IL-6) and 12 (IL-12) was again similar in LPS-matured DCs from $a k t 2^{+/+}$and akt2\% mice (Fig. 1C).

Impaired migration of LPS-matured akt2\% DCS

It has been shown that immature DCs migrate towards the chemokine CXCL12, whereas mature DCs migrate towards CCR7 ligands, such as CCL21 [27]. Migratory capacity of immature akt2\%DCs in response to the CXCL12 chemokine as well as spontaneous migration was not significantly different from $a k t 2^{+/+} \mathrm{DCs}$ (Fig. 1D). However, in contrast to LPS-matured $a k t 2^{+/+}$DCs, LPS-matured $a k t 2 \%$ DCs failed to significantly enhance migration in response to the chemokine CCL21 (25 ng/ml) (Fig. 1E).

Reduced $\mathrm{Ca}^{2+}$ release and store-operated $\mathrm{Ca}^{2+}$ entry in akt $2 \% \mathrm{DCs}$

Fura2-fluorescence has been employed to determine, whether the difference in migratory activity of LPS-matured $a k t 2 \%$ DCs was paralleled by differences in the regulation of cytosolic $\mathrm{Ca}^{2+}$ concentration $\left(\left[\mathrm{Ca}^{2+}\right]_{\mathrm{i}}\right)$. As illustrated in Fig. 2, both slope and peak of CCL21 $(75 \mathrm{ng} / \mathrm{ml})$-induced increase of $\left[\mathrm{Ca}^{2+}\right]_{\mathrm{i}}$ were significantly less pronounced in LPS-matured DCs from $a k t 2 \%$ mice than in DCs from akt2 ${ }^{+/+}$mice. Chemokine-induced increase of $\left[\mathrm{Ca}^{2+}\right]_{\mathrm{i}}$ is known to be due to the release of $\mathrm{Ca}^{2+}$ from intracellular stores followed by the activation of store operated $\mathrm{Ca}^{2+}$ entry (SOCE) $[6,28]$. Therefore, further experiments addressed the impact of Akt2 on $\mathrm{Ca}^{2+}$ release from intracellular stores and on SOCE activity in LPS-matured DCs. As indicated in Fig. 3(A, B), the addition of sarcoendoplasmatic reticulum $\mathrm{Ca}^{2+}$ ATPase (SERCA) inhibitor thapsigargin $(1 \mu \mathrm{mol} / \mathrm{l})$ in the absence of extracellular $\mathrm{Ca}^{2+}$ was followed by an increase of $\left[\mathrm{Ca}^{2+}\right]_{i}$, reflecting release of $\mathrm{Ca}^{2+}$ from intracellular stores. The slope and the peak of the intracellular $\mathrm{Ca}^{2+}$ release were significantly decreased in mature DCs from $a k t 2 \%$ mice (Fig. 3B). The readdition of extracellular $\mathrm{Ca}^{2+}$ in the continued presence of thapsigargin resulted in a rapid increase of $\left[\mathrm{Ca}^{2+}\right]_{i}$, reflecting SOCE. Both, peak and slope of SOCE were significantly higher in DCs from akt2 ${ }^{+/+}$mice than in DCs from akt2\% mice. Release of $\mathrm{Ca}^{2+}$ induced by physiological $\mathrm{IP}_{3}$ formation could be assessed through the stimulation of DCs via P2Y receptors with low concentrations of ATP [29]. Accordingly, ATP (100 $\mu \mathrm{M})$-induced 


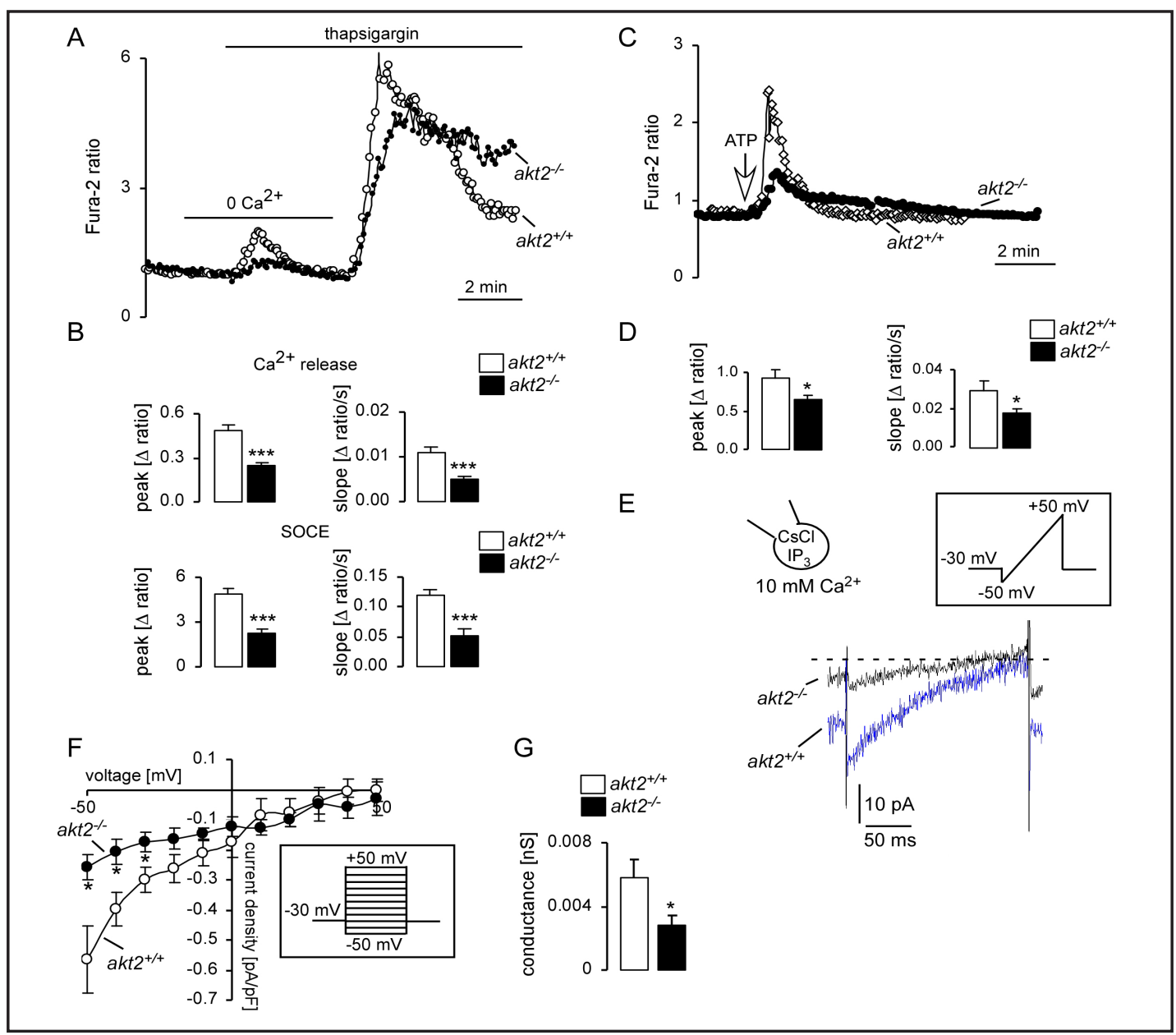

Fig. 3. Reduced $\mathrm{Ca}^{2+}$ release and store-operated $\mathrm{Ca}^{2+}$ entry in akt $2 \%$ DCs. A. Representative tracing showing the Fura-2 fluorescence ratio in LPS $(1 \mu \mathrm{g} / \mathrm{ml})$-matured $a k t 2^{+/+}$and $a k t 2^{-/} \mathrm{DCs}$. Where indicated, thapsigargin $(1 \mu \mathrm{mol} / \mathrm{l})$ was added to the $\mathrm{Ca}^{2+}$-free bath solution and the release of $\mathrm{Ca}^{2+}$ from the stores was assessed. Readdition of extracellular $\mathrm{Ca}^{2+}$ in the presence of thapsigargin reflects SOCE. B. Arithmetic means $( \pm$ SEM) of the slope and the peak of the change in Fura- 2 fluorescence following addition of thapsigargin $(1 \mu \mathrm{mol} / \mathrm{l})$ in the absence $\left(\mathrm{Ca}^{2+}\right.$ release, upper bars) and in the presence of extracellular $\mathrm{Ca}^{2+}$ (SOCE, lower bars) to mature akt2 $^{+/+}(\mathrm{n}=117)$ and $a k t 2^{\%}(\mathrm{n}=75)$ DCs. ${ }^{* * *}(\mathrm{p}<0.001)$, unpaired $t$-test. C. Representative tracing showing the Fura-2 fluorescence ratio in LPS $(1 \mu \mathrm{g} / \mathrm{ml})$-matured $a k t 2^{+/+}$and $a k t 2^{\%}$ DCs upon addition of ATP $(100 \mu \mathrm{mol} / \mathrm{l})$ to the $\mathrm{Ca}^{2+}$-free bath solution. D. Arithmetic means $( \pm \mathrm{SEM}, \mathrm{n}=242-250)$ of the slope and the peak of the change in Fura-2 fluorescence following addition of ATP $(100 \mu \mathrm{mol} / \mathrm{l})$ as in C. $*(\mathrm{p}<0.05)$, unpaired $t$-test. E. Original tracings of the $\mathrm{IP}_{3}(40 \mu \mathrm{mol} / \mathrm{l})$-activated current fraction recorded from LPS $(1 \mu \mathrm{g} / \mathrm{ml})$-matured akt2 $2^{++}$and $a k t 2 \%$ DCs after stimulation with a ramp voltage. The voltage protocol is shown (not to scale), whereby cells were held at $-30 \mathrm{mV}$ and ramps were applied for $200 \mathrm{~ms}$ from $-50 \mathrm{mV}$ to $+50 \mathrm{mV}$. F. Mean currentvoltage (I/V) relationships of currents activated by $40 \mu \mathrm{M} \mathrm{IP}_{3}$ normalized to cell capacitance in LPS (1 $\mu \mathrm{g} /$ $\mathrm{ml})$-matured $a k t 2^{+/+}(\mathrm{n}=15)$ and $a k t 2 \%(\mathrm{n}=11)$ DCs. The voltage protocol is shown (not to scale), whereby cells were held at $-30 \mathrm{mV}$ and voltage steps were applied in $10 \mathrm{mV}$ increments for $200 \mathrm{~ms}$ from $-50 \mathrm{mV}$ to $+50 \mathrm{mV}^{*}(\mathrm{p}<0.05)$, unpaired $t$-test. G. Mean whole-cell conductance of inward currents $( \pm \mathrm{SEM}, \mathrm{n}=11-15)$ calculated by linear regression of I/V curves shown in (F) between $-40 \mathrm{mV}$ and $0 \mathrm{mV} .^{*}(\mathrm{p}<0.05)$, unpaired t-test.

release of $\mathrm{Ca}^{2+}$ (measured in the absence of extracellular $\mathrm{Ca}^{2+}$ ) was lower in LPS-matured akt2\% than in akt2 ${ }^{+/+}$DCs (Fig. 3C, D).

Reduced SOCE in mature akt2\% DCs could be confirmed by whole cell patch clamp recordings. As illustrated in Fig. 3(E-G), the $\mathrm{Ca}^{2+}$ release activated $\mathrm{Ca}^{2+}$ current $\mathrm{I}_{\text {CRAC }}$ triggered 


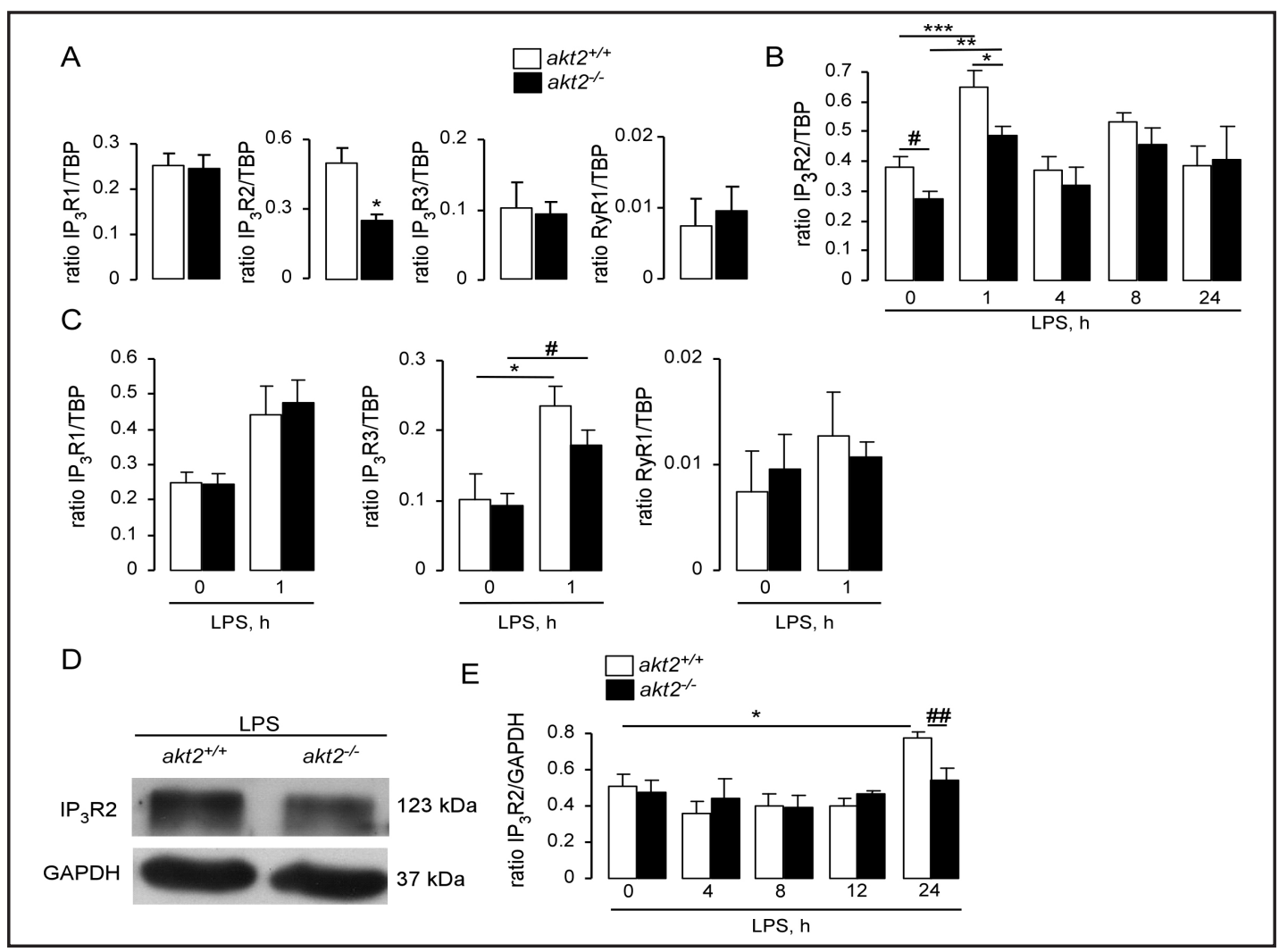

Fig. 4. Reduced expression of $\mathrm{IP}_{3}$ receptor 2 in akt2\% DCs. A. Arithmetic means $( \pm \mathrm{SEM}, \mathrm{n}=3$ ) of the abundance of mRNA encoding the $\mathrm{IP}_{3}$ receptors: $\mathrm{IP}_{3} \mathrm{R} 1, \mathrm{IP}_{3} \mathrm{R} 2$, and $\mathrm{IP}_{3} \mathrm{R} 3$ and the ryanodine receptor RyR1 in immature $a k t 2^{+/+}$and $a k t 2^{\%} \mathrm{DCs}$ as assessed by real-time PCR using Tbp mRNA as a reference gene. $*(\mathrm{p}<0.05)$, unpaired $t$-test. B. Arithmetic means $( \pm \mathrm{SEM}, \mathrm{n}=6-13)$ of the $\mathrm{IP}_{3} \mathrm{R} 2 \mathrm{mRNA}$ abundance in akt2 $2^{+/+}$ and $a k t 2 \%$ DCs unstimulated (LPS, $0 \mathrm{~h})$ and stimulated with LPS $(1 \mu \mathrm{g} / \mathrm{ml}, 1 \mathrm{~h}, 4 \mathrm{~h}, 8 \mathrm{~h}$ and $24 \mathrm{~h}) .{ }^{*}(\mathrm{p}<0.05)$, $* *(\mathrm{p}<0.01),{ }^{* * *}(\mathrm{p}<0.001)$, ANOVA; \# $(\mathrm{p}<0.05)$, only with unpaired $t$-test. C. Arithmetic means $( \pm \mathrm{SEM}, \mathrm{n}=3-$ 6) of the IP ${ }_{3} \mathrm{R} 1, \mathrm{IP}_{3} \mathrm{R} 3$ and RyR1 mRNA abundance in $a k t 2^{+/+}$and $a k t 2^{\%}$ DCs unstimulated (LPS, 0h) and stimulated with LPS $(1 \mu \mathrm{g} / \mathrm{ml}, 1 \mathrm{~h}) .{ }^{*}(\mathrm{p}<0.05)$, ANOVA; \# $(\mathrm{p}<0.05)$, only with unpaired $t$-test. D. Western blot of whole cell lysate protein of IP ${ }_{3} \mathrm{R} 2$ and GAPDH in LPS $(1 \mu \mathrm{g} / \mathrm{ml}, 24 \mathrm{~h})$-matured $a k t 2^{+/+}$and $a k t 2^{\%}$ DCs. E. Arithmetic means \pm SEM ( $\mathrm{n}=3-16)$ of $\mathrm{IP}_{3} \mathrm{R} 2 / \mathrm{GAPDH}$ ratio in immature and LPS (1 $\left.\mu \mathrm{g} / \mathrm{ml}, 4-24 \mathrm{~h}\right)$-treated $a k t 2^{+/+}$and $a k t 2^{-/-}$DCs. ${ }^{*}(\mathrm{p}<0.05)$, ANOVA, \#\# $(\mathrm{p}<0.01)$, only with unpaired $t$-test.

by $\mathrm{IP}_{3}$-induced $\mathrm{Ca}^{2+}$ store depletion was significantly higher in LPS-matured DCs from akt2 $^{+/+}$ mice than in akt2\% DCs.

\section{Reduced expression of IP3 receptor 2 in akt2\% DCs}

Impaired $\mathrm{Ca}^{2+}$ release, SOCE and $\mathrm{I}_{\mathrm{CRAC}}$ in akt2\% DCs could have resulted from Akt2 sensitivity of the $\mathrm{Ca}^{2+}$ release pathways such as inositoltrisphosphate receptors IP ${ }_{3} \mathrm{Rs}$ or the ryanodine receptor RyR1. As illustrated in Fig. 4A, transcript levels of $I_{3} R_{1} 1, I_{3} R 3$ and RyR1 were similar in immature $a k t 2^{+/+}$and $a k t 2^{\%} \mathrm{DCs}$, whereas the transcript abundance of $\mathrm{IP}_{3} \mathrm{R} 2$ was significantly higher in akt2/++ DCs than in akt2\% DCs. Stimulation of $a k t 2^{+/+}$DCs with LPS $(1 \mu \mathrm{g} / \mathrm{ml})$ resulted in a transient upregulation of $\mathrm{IP}_{3} \mathrm{R} 2$ transcript abundance within $1 \mathrm{~h}$ in $a k t 2^{+/+} \mathrm{DCs}$, an effect significantly impaired in $a k t 2 \%$ DCs (Fig. 4B). Stimulation of DCs with LPS $(1 \mu \mathrm{g} / \mathrm{ml}, 1 \mathrm{~h})$ further tended to upregulate $\mathrm{IP}_{3} \mathrm{R} 1$ and $\mathrm{IP}_{3} \mathrm{R} 3$, an effect reaching statistical significance for $I_{3} R 3$ (Fig. 4C). The effect of LPS on IP ${ }_{3} R 1$ and $I_{3} R 3$ was not siginificantly different between genotypes. In neither genotype, LPS did significantly modify RyR1 transcript levels. 


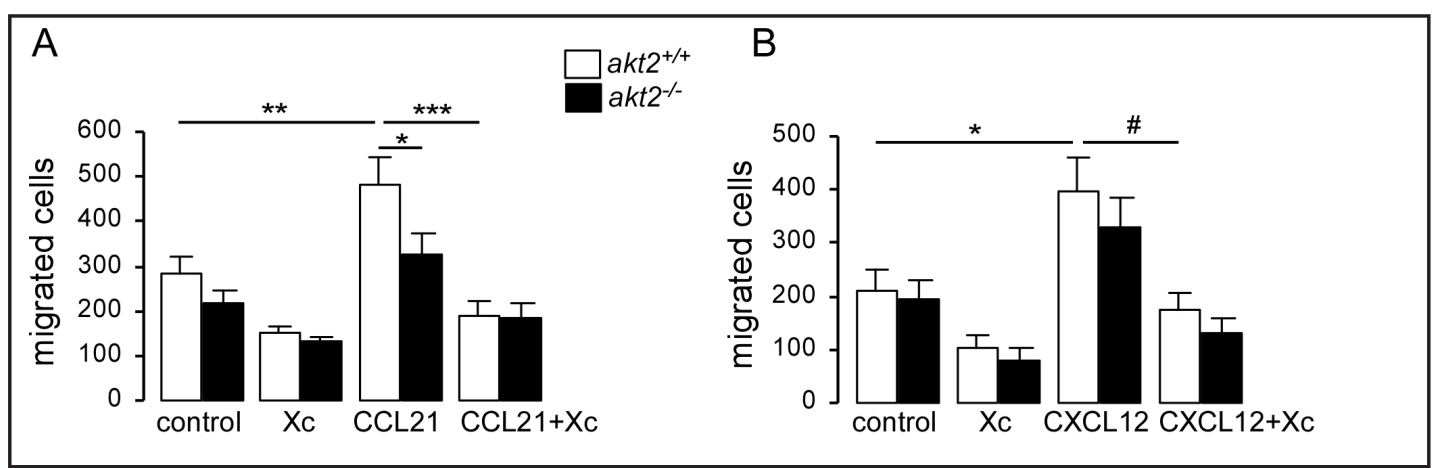

Fig. 5. Migration of $a k t 2^{+/+}$and $a k t 2 \%$ DCs is sensitive to the $\mathrm{IP}_{3} \mathrm{R}$ inhibitor Xestospongin C. Arithmetic means \pm SEM $(n=5-25)$ of spontaneous migration and migration in response to either CCL21 $(25 \mathrm{ng} / \mathrm{ml}, 4 \mathrm{~h}$, LPS $(1 \mu \mathrm{g} / \mathrm{ml}, 24 \mathrm{~h})$-matured DCs, A) or CXCL12 (50 ng/ml, 4h, immature DCs, B) of akt2 ${ }^{+/+}$and $a k t 2 \%$ DCs in the absence or in the presence of the $\operatorname{IP}_{3} \mathrm{R}$ inhibitor Xestospongin $\mathrm{C}(\mathrm{Xc}, 5 \mu \mathrm{mol} / \mathrm{l}, 3 \mathrm{~h}) *(\mathrm{p}<0.05)$, ** $(\mathrm{p}<0.01)$, $* * *(\mathrm{p}<0.001)$, ANOVA; \# $(\mathrm{p}<0.05)$, only with unpaired $t$-test.

Fig. 6. Reduced expression of the transcription factor Ets1 in $a k t 2 \%$ DCs. A. The lysates of immature and LPS $(1 \mu \mathrm{g} / \mathrm{ml}, 24 \mathrm{~h})$ matured akt2+/+ and akt2\% DCs were immunoprecipitated with a phosphospecific antibody that detects the consensus Akt phosphorylation sequence (RXRXX(S/T)) and then immunoblotted with $\mathrm{IP}_{3} \mathrm{R} 2$ antibody. B. Arithmetic means $( \pm$ SEM, $n=6$ ) of the Ets1 mRNA abundance in immature $a k t 2^{+/+}$and akt2\% DCs. ${ }^{*}(\mathrm{p}<0.05)$, unpaired $t$-test. C. Arithmetic means ( \pm SEM, $n=6-9$ ) of the Ets1 mRNA abundance in akt2 $2^{+/}$and $a k t 2 \%$ DCs, unstimulated (LPS, 0h) and stimulated with LPS $(1 \mu \mathrm{g} / \mathrm{ml}$, $1 \mathrm{~h}$ and $4 \mathrm{~h}) .{ }^{* *}(\mathrm{p}<0.01)$, ANOVA; \# $(\mathrm{p}<0.05)$, only with unpaired $t$-test. D. Western blot of whole

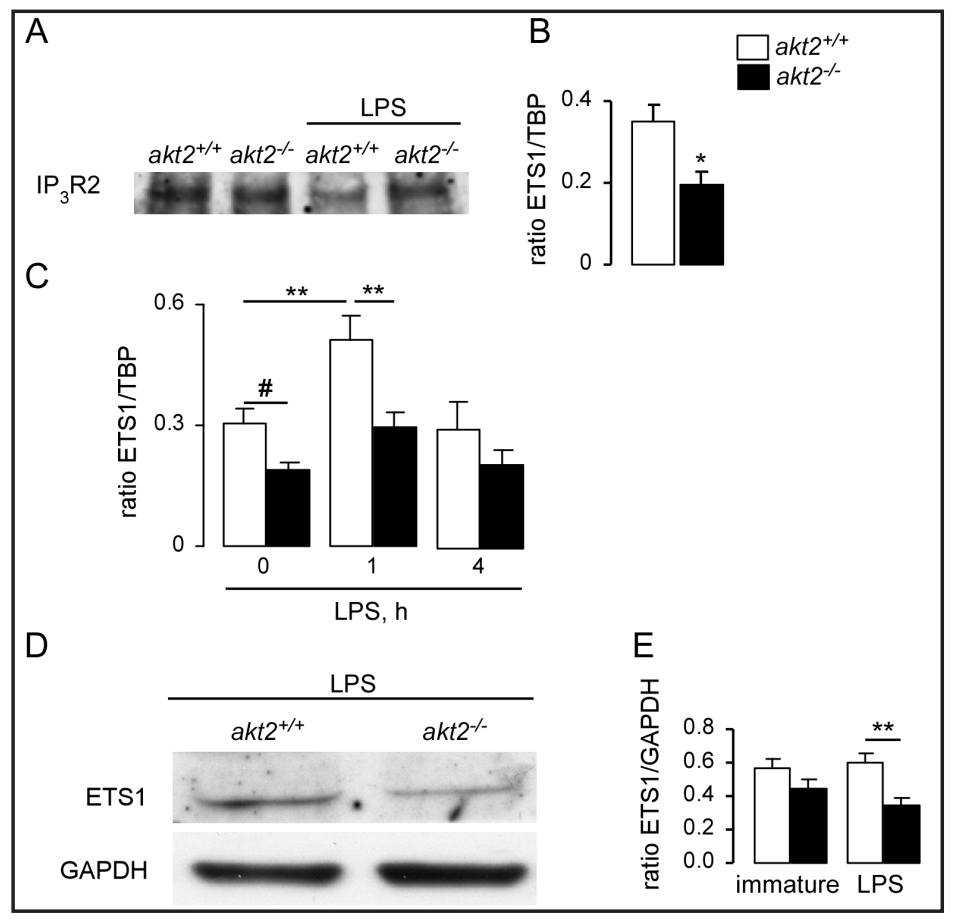

cell lysate protein of ETS1 and GAPDH in LPS $(1 \mu \mathrm{g} / \mathrm{ml}, 24 \mathrm{~h})$-matured $a k t 2^{+/+}$and $a k t 2 \%$ DCs. E. Arithmetic means \pm SEM $(\mathrm{n}=6)$ of ETS1/GAPDH ratio in immature and LPS $(1 \mu \mathrm{g} / \mathrm{ml}, 24 \mathrm{~h})$-matured $a k t 2^{+/+}$and $a k t 2^{\%}$ DCs. $* *(p<0.01)$, ANOVA.

Western blot analysis was employed to elucidate whether the differences in transcript levels were paralleled by similar differences in $\mathrm{IP}_{3} \mathrm{R} 2$ protein abundance. Prior to maturation and upon LPS ( $1 \mu \mathrm{g} / \mathrm{ml}$ ) treatment for $4 \mathrm{~h}, 8 \mathrm{~h}$ and $12 \mathrm{~h}$, the $\mathrm{IP}_{3} \mathrm{R} 2$ protein abundance was similar in $a k t 2^{+/+}$and $a k t 2^{\%}$ DCs (Fig. 4D, E). However, $24 \mathrm{~h}$ after LPS treatment a significant increase of $\mathrm{IP}_{3} \mathrm{R} 2$ protein abundance was observed in $a k t 2^{+/+} \mathrm{DCs}$, but not in $a k t 2^{\%}$ DCs (Fig. 4D, E).

DC Migration is sensitive to the IP3R inhibitor Xestospongin C

To further address the functional significance of Akt2 sensitive $\mathrm{IP}_{3} \mathrm{R} 2$ regulation, migratory capacity was tested in LPS-matured DCs from $a k t 2^{+/+}$and $a k t 2^{\%}$ mice in the absence 
Fig. 7. Silencing of the transcription factor ETS1 in LPS-matured $a k t 2^{+/+}$DCs reduces $\mathrm{Ca}^{2+}$ release, store-operated $\mathrm{Ca}^{2+}$ entry, I $\mathrm{IRAC}$ and migration. A. Western blot analysis of whole cell lysate protein of ETS1 in immature control (control siRNA) and siEts1DCs. Representative experiments showing ETS1 band and GAPDH as loading control. B. Arithmetic means $( \pm$ SEM) of the Ets1 $(n=14)$ and $\mathrm{IP}_{3} \mathrm{R} 2 \quad(\mathrm{n}=7)$ mRNA abundance in LPS ( $1 \mathrm{mg} / \mathrm{ml}, 1$ h)-treated control (control siRNA) and siETS1-DCs. $*(\mathrm{p}<0.05), \quad$ unpaired $t$-test. $C$. Fura-2 fluorescence ratio in LPS (1 $\mu \mathrm{g} / \mathrm{ml}, 24 \mathrm{~h}$ )matured control (control siRNA) and siEts1-DCs upon exposure to
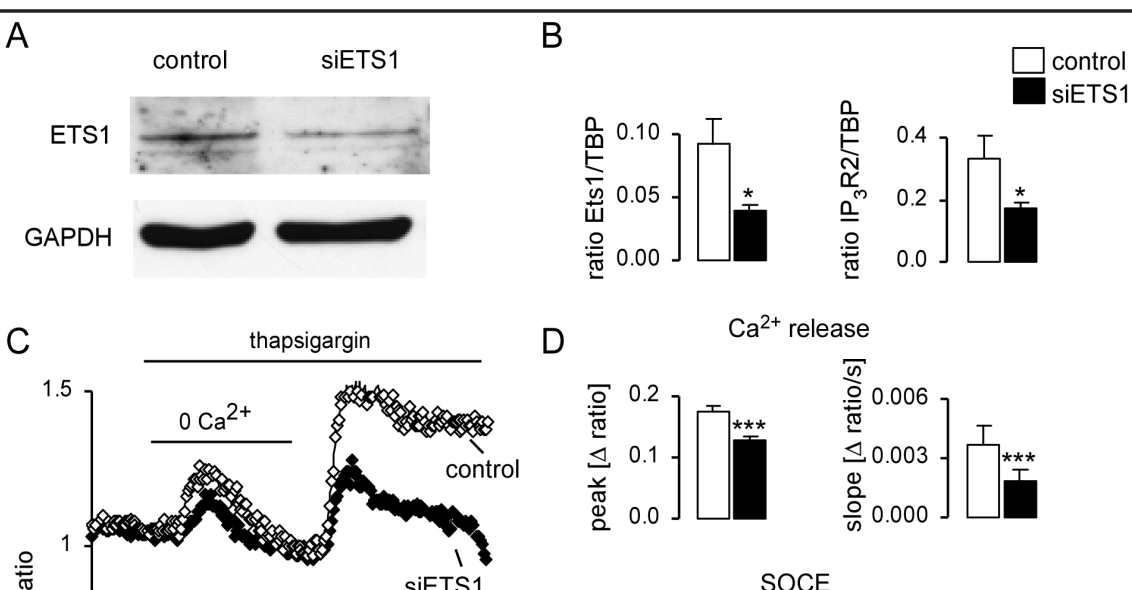

$\mathrm{Ca}^{2+}$ release
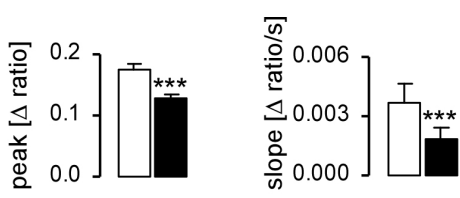

SOCE
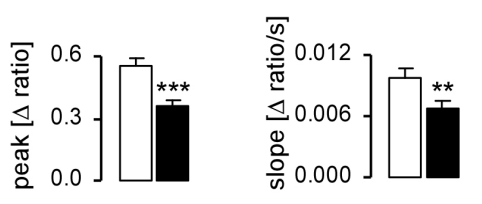

$\mathrm{F}$

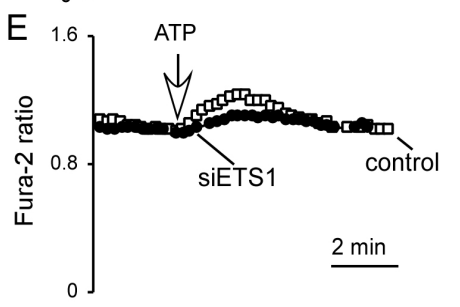

$\mathrm{H}$
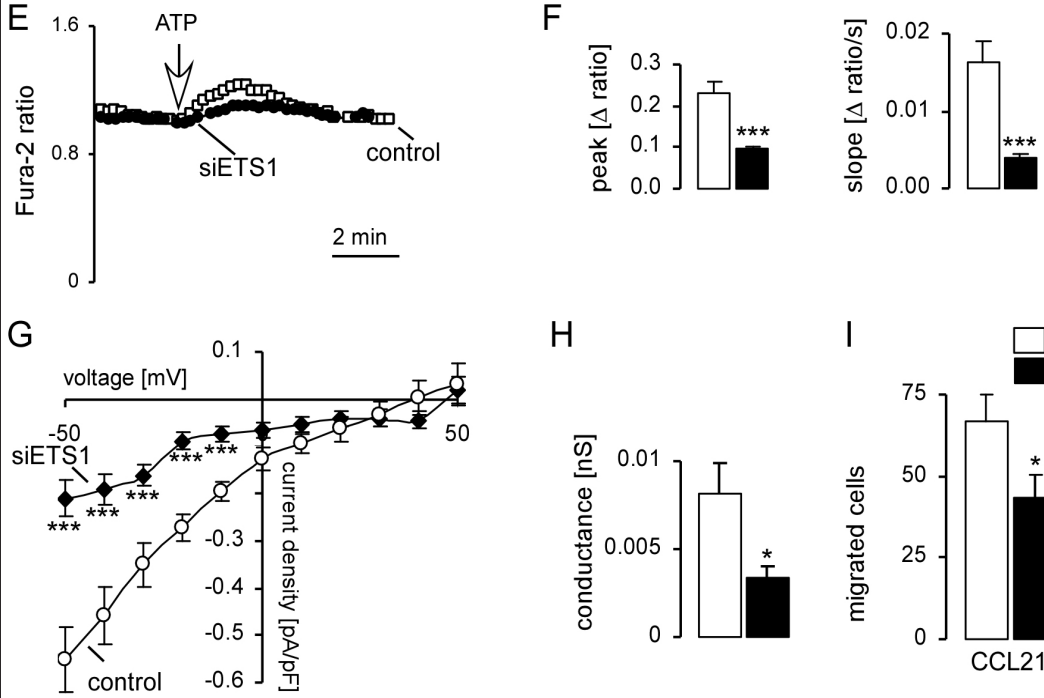

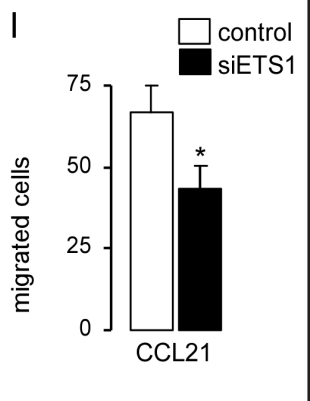

thapsigargin $(1 \mu \mathrm{mol} / \mathrm{l})$ in the $\mathrm{Ca}^{2+}$-free bath solution followed by readdition of extracellular $\mathrm{Ca}^{2+}$. D. Arithmetic means $( \pm$ SEM) of the peak and the slope of the change in Fura-2 fluorescence following addition of thapsigargin $(1 \mu \mathrm{mol} / \mathrm{l})$ in the absence and in the presence of extracellular $\mathrm{Ca}^{2+}$ to LPS $(1 \mathrm{mg} / \mathrm{ml}, 24$ h)-matured control $(\mathrm{n}=55)$ and siEts1 $(\mathrm{n}=103)$ DCs. ${ }^{* *}(\mathrm{p}<0.01),{ }^{* * *}(\mathrm{p}<0.001)$, unpaired $t$-test. E. Fura-2 fluorescence ratio in LPS $(1 \mu \mathrm{g} / \mathrm{ml}, 24 \mathrm{~h}$ )-matured control (control siRNA) and siEts1-DCs upon addition of ATP $(100 \mu \mathrm{mol} / \mathrm{l})$ to the $\mathrm{Ca}^{2+}$-free bath solution. F. Arithmetic means $( \pm \mathrm{SEM}, \mathrm{n}=38-61)$ of the peak and the slope of the change in Fura-2 fluorescence following addition of ATP $(100 \mu \mathrm{mol} / \mathrm{l})$ as in E. *** $(\mathrm{p}<0.001)$, unpaired $t$-test. G. Mean I/V relationships of currents activated by $40 \mu \mathrm{mol} / \mathrm{l} \mathrm{IP}_{3}$ normalized to cell capacitance in LPS $(1 \mu \mathrm{g} / \mathrm{ml}, 24 \mathrm{~h})$-matured control $(\mathrm{n}=20)$ and siEts $1(\mathrm{n}=17)$ DCs. ${ }^{* * *}(\mathrm{p}<0.001)$, unpaired $t$-test. $\mathrm{H}$. Mean whole-cell conductance of inward currents ( \pm SEM, $n=17-20$ ) calculated by linear regression of $\mathrm{I} / \mathrm{V}$ curves shown in $(\mathrm{G})$ between -40 and $0 \mathrm{mV}$ * $(\mathrm{p}<0.05)$, unpaired $t$-test. I. Arithmetic means $\pm \operatorname{SEM}(\mathrm{n}=11)$ of CCL21 (25 ng/ml, 4h)-induced migration in LPS ( $1 \mu \mathrm{g} / \mathrm{ml}, 24 \mathrm{~h})$-matured control (control siRNA) and siEts1 DCs. ${ }^{*}(\mathrm{p}<0.05)$, unpaired $t$-test.

and presence of $\mathrm{IP}_{3} \mathrm{R}$ inhibitor Xestospongin $\mathrm{C}(5 \mu \mathrm{mol} / \mathrm{l})$. Xestospongin $\mathrm{C}$ significantly decreased the migratory activity of CCL21-treated LPS-matured $a k t 2^{+/+}$DCs and abrogated 
Fig. 8. Tentative model of Akt2dependent $\mathrm{Ca}^{2+}$ signaling and migration in DCs. Red arrows represent the novel contribution of the present study.

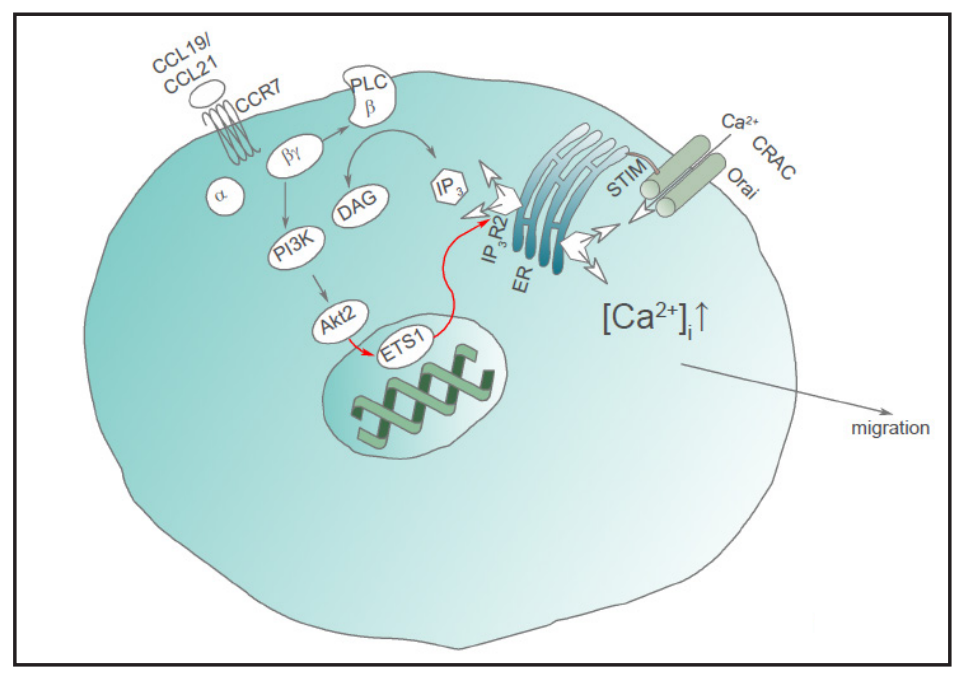

the differences in migratory activity between DCs from akt2 $2^{+/+}$and $a k t 2 \%$ mice (Fig. 5A). CXCL12-induced migration of immature DCs was also sensitive to Xestospongin C. However, CXCL12-induced migration of immature DCs was not significantly different between $a k t 2 \%$ and $a k t 2^{+/+}$DCs (Fig. 5B).

$\mathrm{PKB} /$ Akt has previously beeen shown to phosphorylate $\mathrm{IP}_{3} \mathrm{R}$, reducing its sensitivity to $\mathrm{IP}_{3}$ and diminishing $\mathrm{Ca}^{2+}$ release [30]. We thus examined the phosphorylation status of $\mathrm{IP}_{3} \mathrm{R} 2$ by immunoprecipitating the lysates with a phosphospecific antibody that detects the consensus Akt phosphorylation sequence $\left(\mathrm{RXRXX}(\mathrm{S} / \mathrm{T})\right.$ ) and immunoblotting with $\mathrm{IP}_{3} \mathrm{R} 2$ specific antibody (Fig. 6A). IP ${ }_{3}$ R2 was phosphorylated in immature as well as in LPS-matured DCs. However no significant difference was detected between $a k t 2^{+/+}$and $a k t 2^{\%}$ DCs.

\section{Reduced expression of the transcription factor ETS1 in akt2\%DCs}

According to previous observations, expression of $\mathrm{IP}_{3} \mathrm{R} 3$ in $\mathrm{CD} 4^{+} \mathrm{T}$ cells requires the ETS1 transcription factor [31]. In ETS1-deficient CD4 $T$ cells the level of $\mathrm{IP}_{3} \mathrm{R} 2$ protein was also reduced [31]. Moreover, activated Akt has been shown to lead to increased ETS1 transcription [32]. Therefore we next examined the transcript level of ETS1 in akt2\% and $a k t 2^{+/+}$DCs. The transcript abundance of ETS1 was significantly lower in immature akt2\% DCs than in immature $a k t 2^{+/+}$DCs (Fig. 6B). Moreover, similar to its effect on IP ${ }_{3}$ R2, LPS (1 $\mu \mathrm{g} / \mathrm{ml}$ ) induced a transient increase in ETS1 transcript level within $1 \mathrm{~h}$ in $a k t 2^{+/+} \mathrm{DCs}$, but not in akt2\% DCs (Fig. 6C). Accordingly, the protein abundance of ETS1 in LPS-matured akt2\% DCs was significantly decreased (Fig. 6D, E).

Silencing of the transcription factor ETS1 in LPS-matured akt2+/+ DCs reduces $\mathrm{Ca}^{2+}$ release, store-operated $\mathrm{Ca}^{2+}$ entry, $I_{C R A C}$ and migration

In order to test whether Akt2-dependent ETS1 expression contributes to decreased $\mathrm{IP}_{3} \mathrm{R} 2$ expression and function in akt2\% DCs, we suppressed ETS1 expression with siRNA (Fig. 7). The efficiency of silencing assessed with RT-PCR was $47 \pm 11 \%(n=7)$ and was confirmed by western blotting (Fig. 7A). Upon LPS stimulation (1h), ETS1 and IP R2 transcript abundance were reduced in siETS1 DCs (Fig. 7B). The discrepancy in the IP ${ }_{3} \mathrm{R} 2$ transcript abundance shown in Fig. 4B and in this series of experiments is most probably due to the influence of siRNAs on DC maturation [33]. Thapsigargin-induced (Fig. 7C, D) and ATP-induced (Fig. 7E, F) $\mathrm{Ca}^{2+}$ release, thapsigargin-induced SOCE (Fig. 7C, D), as well as $\mathrm{I}_{\text {CRAC }}$ (Fig. 7G, H) were significantly impaired in siETS1 LPS (24 h)-matured DCs. Moreover, CCL21-dependent migration was significantly decreased in siETS1- LPS (24 h)-matured DCs (Fig. 7I). Those data strongly suggest that Akt2 upregulates ETS1 transcription leading to enhanced expression of $\mathrm{IP}_{3} \mathrm{R} 2$, increased $\mathrm{Ca}^{2+}$ release and increased store-operated $\mathrm{Ca}^{2+}$ entry, which at least partially account for the effect of Akt2 on DC migration. 


\section{Discussion}

In the present study we demonstrate that Akt2 up-regulates the expression of $\mathrm{IP}_{3} \mathrm{R} 2$ in mouse DCs and thus enhances release of $\mathrm{Ca}^{2+}$ from intracellular stores. Accordingly, store-operated $\mathrm{Ca}^{2+}$ entry and current through $\mathrm{Ca}^{2+}$ release-activated $\mathrm{Ca}^{2+}(\mathrm{CRAC})$ channels are decreased in Akt2 deficient DCs. Moreover, we provide evidence that IP ${ }_{3} \mathrm{R} 2$ expression in DCs is regulated by the Akt2-dependent transcription factor ETS1. Finally, we show that reduced $I_{3} \mathrm{R} 2$ expression contributes to or even accounts for impaired migration of Akt2deficient DCs (Fig. 8).

Within 1 hour of LPS-induced maturation, the transcript abundance of IP 32 was transiently enhanced in akt2 $2^{++}$and to a lesser extent in akt2\% DCs. As a consequence, the protein abundance of $\mathrm{IP}_{3} \mathrm{R} 2$ was increased $24 \mathrm{~h}$ after LPS addition in akt2+/+ DCs. In akt2 $\%$ DCs, the protein level of $\mathrm{IP}_{3} \mathrm{R} 2$ also tended to be higher $24 \mathrm{~h}$ after LPS than prior to LPS treatment, a difference, however, not reaching statistical significance. The apparent inability of $a k t 2 \%$ DCs to strongly upregulate $\mathrm{IP}_{3} \mathrm{R} 2$ expression resulted in an impaired function of $\mathrm{IP}_{3} \mathrm{Rs}$ in mature $a k t 2 \% \mathrm{DCs}$, as demonstrated by reduced $\mathrm{Ca}^{2+}$ release induced by $\mathrm{P} 2 \mathrm{Y}$ receptor engagement or by inhibition of sarcoendoplasmatic reticulum $\mathrm{Ca}^{2+}$ ATPase (SERCA) with thapsigargin. Consequently, store-operated $\mathrm{Ca}^{2+}$ entry and $\mathrm{IP}_{3}$-induced activation of CRAC channels were significantly blunted in Akt2-deficient DCs. Most importantly, increase of cytosolic free $\mathrm{Ca}^{2+}$ concentration upon ligation of the CCR7 was strongly reduced in mature akt2\% DCs, which was paralleled by reduced CCR7-dependent migration of those cells. $\mathrm{IP}_{3} \mathrm{R}$ inhibitor Xestospongin C inhibited CCR7-dependent migration and abrogated the difference in migrating ability between $a k t 2^{+/+}$and $a k t 2 \%$ DCs. This allows us to conclude that reduced expression of $\mathrm{IP}_{3} \mathrm{R} 2$ underlies, at least partially, the defective CCR7-dependent migration of Akt2-deficient DCs. Akt2 knockdown has similarly been shown to result in reduced plasmintriggered migration of human DCs [7], and CSF-1- and MCP-1-induced chemotaxis of mouse peritoneal macrophages [9].

Akt2-dependent release of $\mathrm{Ca}^{2+}$ through the $\mathrm{IP}_{3} \mathrm{R} 2$ would be in line with the well established PI3K-dependent upregulation of $\mathrm{Ca}^{2+}$ mobilization in lymphocytes. Phosphorylation of Akt/PKB is compromised and $\mathrm{Ca}^{2+}$ flux in response to stimulation of $\mathrm{B}$ and $\mathrm{T}$ cell antigen receptors is attenuated in $\mathrm{B}$ and $\mathrm{T}$ lymphocytes deficient in the catalytic subunit of PI3K, p110 $\delta$ [12]. Diminished $\mathrm{Ca}^{2+}$ mobilization in B cells with either genetic or pharmacologic inhibition of p110 $\delta$ has also been confirmed in other studies [13-15]. The present study suggests that in DCs PI3K-sensitive $\mathrm{Ca}^{2+}$ mobilisation at least partially results from Akt2-dependent $\mathrm{IP}_{3} \mathrm{R}$ expression. In DT40 B cells and Jurkat cells a seeming inhibiting effect of Akt2 on $\mathrm{Ca}^{2+}$ mobilization has been observed [34]. Whereas the initial amplitude of $\mathrm{Ca}^{2+}$ mobilization was not influenced by Akt2, the subsequent clearance of $\mathrm{Ca}^{2+}$ was accelerated by Akt2, which shortened the increase of cytosolic $\mathrm{Ca}^{2+}$ concentration and blunted the activation of NFAT [34]. The mechanism of Akt2-dependent reduction of $\mathrm{Ca}^{2+}$ mobilization proposed by Martin et al. involves Akt2 interaction with Bcl-2 proteins, which bind to $\mathrm{IP}_{3} \mathrm{R}$ thus inhibiting $\mathrm{Ca}^{2+}$ release [34]. Accordingly, a cell permeable peptide that blocks the interaction between Bcl-2 and $\mathrm{IP}_{3} \mathrm{R}$ abrogated the effect of Akt2 [34]. However, enhanced $\mathrm{Ca}^{2+}$ clearance rather than modified $\mathrm{Ca}^{2+}$ release measured in the presence of Akt2 may result also from Akt2-dependent upregulation of SERCA or any other extrusion pathway in this model.

Several mechanisms of Akt-dependent regulation of $\mathrm{IP}_{3} \mathrm{Rs}$ have been determined so far. A direct interaction and phosphorylation of $\mathrm{IP}_{3} \mathrm{R}$ by Akt has been demonstrated [30, 35]. Szado et al. have shown that Akt-dependent phosphorylation of $\mathrm{IP}_{3} \mathrm{Rs}$ significantly reduces their $\mathrm{Ca}^{2+}$ release activity [30]. Another study of Khan et al. has not revealed any modification of $\mathrm{IP}_{3} \mathrm{R}$ function by Akt phosphorylation [35]. We could detect phosphorylation of IP ${ }_{3} \mathrm{R} 2$ at the Akt specific motif, however no difference in phosphorylated $\mathrm{IP}_{3} \mathrm{R} 2$ was observed between $a k t 2 \%$ and $a k t 2^{+/+}$DCs. Another proposed mechanism involves Akt-dependent regulation of Bcl-2 anti-apoptotic proteins [34], which are known to interact with $\mathrm{IP}_{3} \mathrm{R}$ through their antiapoptotic $\mathrm{BH} 4$ domain and to inhibit $\mathrm{Ca}^{2+}$ release [36]. 
The present study discloses an influence of Akt2 on ETS1-dependent transcription of $\mathrm{IP}_{3} \mathrm{R} 2$. ETS1 is a transcription factor highly conserved throughout evolution and highly expressed in lymphocytes and in tumors $[37,38]$. ETS1 seems to mediate the upregulating effect of Akt2 on IP $\mathrm{R} 2$ expression in mouse DCs. The kinetics of ETS1 transcription upon LPS stimulation follows the same pattern as $\mathrm{IP}_{3} \mathrm{R} 2$ with a rapid and transient upregulation of ETS1 transcript abundance $1 \mathrm{~h}$ after LPS treatment. Mature $a \mathrm{kt} 2 \%$ DCs expressed significantly less ETS1 protein than mature akt2//+ DCs. Moreover, $\mathrm{IP}_{3} \mathrm{R} 2 \mathrm{mRNA}$ expression was reduced upon ETS1 knock down. Silencing of ETS1 also resulted in a strong impairment of $\mathrm{Ca}^{2+}$ release induced either by inhibition of SERCA with thapsigargin or by ligation of P2Y receptors with ATP. These results are in accordance with the study on ETS1-deficient CD4 T cells in which $\mathrm{Ca}^{2+}$ mobilization in response to TCR ligation is impaired [31]. In addition, $\mathrm{IP}_{3} \mathrm{R} 3$ has clearly been shown to be under transcriptional regulation by ETS1 [31,39].

ETS1 gene expression is known to be stimulated by activated Akt [32, 40, 41]. In prostate cancer cells elevated Akt ( $\mathrm{v}$-akt murine thymoma viral oncogene homolog) activity has been demonstrated to increase ETS1 protein levels and exogenous ETS1 expression is sufficient to rescue invasive potential, which decreases following Akt inhibition [41]. On the other hand, inhibition of the PI3K/Akt pathway blocked transcriptional upregulation of ETS1 by ER stress in human melanoma cells [42] and by PDGF in human aortic vascular smooth muscle cells [43]. Moreover, knockdown of Akt3 reduced the basal levels of ETS1 in melanoma cells, suggesting that the PI3K/Akt pathway may play a role in regulating constitutive expression of ETS1 [42]. Expression of ETS1 was reduced in $a k t 2 \%$ DCs only upon stimulation with LPS. LPS has been shown to stimulate PI3K with the subsequent Akt phosphorylation in mouse DCs $[44,45]$. Thus, LPS-induced activation of Akt2 is probably required for the continuous expression of ETS1 upon DC maturation.

\section{Conclusion}

Akt2 upregulates $\mathrm{IP}_{3} \mathrm{R} 2$ transcription and protein expression in DCs presumably by enhancing the expression of ETS1. The effect contributes to or even accounts for the stimulating effect of Akt2 on DC migration.

\section{Acknowledgements}

The authos declare that they have no conflicts of interest. The authors acknowledge the meticulous preparation of the manuscript by Tanja Loch. We are grateful to Mykola Holoviznin for graphical support.

\section{References}

1 Randolph GJ, Ochando J, Partida-Sanchez S: Migration of dendritic cell subsets and their precursors. Annu Rev Immunol 2008;26:293-316.

- Forster R, Schubel A, Breitfeld D, Kremmer E, Renner-Muller I, Wolf E, Lipp M: CCR7 coordinates the primary immune response by establishing functional microenvironments in secondary lymphoid organs. Cell 1999;99:23-33.

3 Shumilina E, Huber SM, Lang F: $\mathrm{Ca}^{2+}$ signaling in the regulation of dendritic cell functions. Am J Physiol Cell Physiol 2011;300:C1205-C1214.

4 Matzner N, Zemtsova IM, Nguyen TX, Duszenko M, Shumilina E, Lang F: Ion channels modulating mouse dendritic cell functions. J Immunol 2008;181:6803-6809.

5 Xuan NT, Shumilina E, Matzner N, Zemtsova IM, Biedermann T, Goetz F, Lang F: Ca ${ }^{2+}$-dependent functions in peptidoglycan-stimulated mouse dendritic cells. Cell Physiol Biochem 2009;24:167-176. 
Yang et al.: Akt2- and ETS1-Sensitive $\mathrm{IP}_{3} \mathrm{R} 2$

6 Nurbaeva MK, Schmid E, Szteyn K, Yang W, Viollet B, Shumilina E, Lang F: Enhanced $\mathrm{Ca}^{2+}$ entry and $\mathrm{Na}^{+}$/ $\mathrm{Ca}^{2+}$ exchanger activity in dendritic cells from AMP-activated protein kinase-deficient mice. FASEB J 2012;26:3049-3058.

7 Li X, Syrovets T, Genze F, Pitterle K, Oberhuber A, Orend KH, Simmet T: Plasmin triggers chemotaxis of monocyte-derived dendritic cells through an Akt2-dependent pathway and promotes a T-helper type-1 response. Arterioscler Thromb Vasc Biol 2010;30:582-590.

8 Park D, Lapteva N, Seethammagari M, Slawin KM, Spencer DM: An essential role for Akt1 in dendritic cell function and tumor immunotherapy. Nat Biotechnol 2006;24:1581-1590.

-9 Zhang B, Ma Y, Guo H, Sun B, Niu R, Ying G, Zhang N: Akt2 is required for macrophage chemotaxis. Eur J Immunol 2009;39:894-901.

10 Bhandaru M, Yang W, Rotte A, Pasham V, Lang F: Regulation of $\mathrm{Na}^{+} / \mathrm{H}^{+}$exchanger in dendritic cells by Akt2. Pflugers Arch 2012;463:355-363.

11 Toker A, Yoeli-Lerner M: Akt signaling and cancer: surviving but not moving on. Cancer Res 2006;66:39633966.

12 Okkenhaug K, Bilancio A, Farjot G, Priddle H, Sancho S, Peskett E, Pearce W, Meek SE, Salpekar A, Waterfield MD, Smith AJ, Vanhaesebroeck B: Impaired B and T cell antigen receptor signaling in p110delta PI 3-kinase mutant mice. Science 2002;297:1031-1034.

13 Jou ST, Carpino N, Takahashi Y, Piekorz R, Chao JR, Carpino N, Wang D, Ihle JN: Essential, nonredundant role for the phosphoinositide 3-kinase p110delta in signaling by the B-cell receptor complex. Mol Cell Biol 2002;22:8580-8591.

14 Bilancio A, Okkenhaug K, Camps M, Emery JL, Ruckle T, Rommel C, Vanhaesebroeck B: Key role of the p110delta isoform of PI3K in B-cell antigen and IL-4 receptor signaling: comparative analysis of genetic and pharmacologic interference with p110delta function in B cells. Blood 2006;107:642-650.

$\checkmark 15$ Inabe K, Ishiai M, Scharenberg AM, Freshney N, Downward J, Kurosaki T: Vav3 modulates B cell receptor responses by regulating phosphoinositide 3-kinase activation. J Exp Med 2002;195:189-200.

16 Tessier M, Woodgett JR: Serum and glucocorticoid-regulated protein kinases: variations on a theme. J Cell Biochem 2006;98:1391-1407.

-17 Borst O, Schmidt EM, Munzer P, Schonberger T, Towhid ST, Elvers M, Leibrock C, Schmid E, Eylenstein A, Kuhl D, May AE, Gawaz M, Lang F: The serum- and glucocorticoid-inducible kinase 1 (SGK1) influences platelet calcium signaling and function by regulation of Orai1 expression in megakaryocytes. Blood 2012;119:251-261.

18 Eylenstein A, Gehring EM, Heise N, Shumilina E, Schmidt S, Szteyn K, Munzer P, Nurbaeva MK, Eichenmuller M, Tyan L, Regel I, Foller M, Kuhl D, Soboloff J, Penner R, Lang F: Stimulation of Ca ${ }^{2+}$-channel Orai1/STIM1 by serum- and glucocorticoid-inducible kinase 1 (SGK1). FASEB J 2011;25:2012-2021.

19 Eylenstein A, Schmidt S, Gu S, Yang W, Schmid E, Schmidt EM, Alesutan I, Szteyn K, Regel I, Shumilina E, Lang F: Transcription factor NF-kappaB regulates expression of pore-forming $\mathrm{Ca}^{2+}$ channel unit, Orai1, and its activator, STIM1, to control Ca2+ entry and affect cellular functions. J Biol Chem 2012;287:2719-2730.

20 Lang F, Eylenstein A, Shumilina E: Regulation of Orai1/STIM1 by the kinases SGK1 and AMPK. Cell Calcium 2012;52:347-354.

-21 Lang F, Shumilina E: Regulation of ion channels by the serum- and glucocorticoid-inducible kinase SGK1. FASEB J 2013;27:3-12.

-22 Cho H, Mu J, Kim JK, Thorvaldsen JL, Chu Q, Crenshaw EB, 3rd, Kaestner KH, Bartolomei MS, Shulman GI, Birnbaum MJ: Insulin resistance and a diabetes mellitus-like syndrome in mice lacking the protein kinase Akt2 (PKB beta). Science 2001;292:1728-1731.

23 Ishii T, Sugita Y, Bannai S: Regulation of glutathione levels in mouse spleen lymphocytes by transport of cysteine. J Cell Physiol 1987;133:330-336.

24 Hamill OP, Marty A, Neher E, Sakmann B, Sigworth FJ: Improved patch-clamp techniques for highresolution current recording from cells and cell-free membrane patches. Pflugers Arch 1981;391:85-100.

25 Barry PH, Lynch JW: Liquid junction potentials and small cell effects in patch-clamp analysis. J Membr Biol 1991;121:101-117.

26 Pfaffl MW: A new mathematical model for relative quantification in real-time RT-PCR. Nucleic Acids Res 2001;29:e45. 
Yang et al.: Akt2- and ETS1-Sensitive $\mathrm{IP}_{3} \mathrm{R} 2$

27 Partida-Sanchez S, Goodrich S, Kusser K, Oppenheimer N, Randall TD, Lund FE: Regulation of dendritic cell trafficking by the ADP-ribosyl cyclase CD38: impact on the development of humoral immunity. Immunity 2004;20:279-291.

-28 Barbet G, Demion M, Moura IC, Serafini N, Leger T, Vrtovsnik F, Monteiro RC, Guinamard R, Kinet JP, Launay $\mathrm{P}$ : The calcium-activated nonselective cation channel TRPM4 is essential for the migration but not the maturation of dendritic cells. Nat Immunol 2008;9:1148-1156.

29 Di Virgilio F: Purinergic mechanism in the immune system: A signal of danger for dendritic cells. Purinergic Signal 2005;1:205-209.

-30 Szado T, Vanderheyden V, Parys JB, De Smedt H, Rietdorf K, Kotelevets L, Chastre E, Khan F, Landegren U, Soderberg O, Bootman MD, Roderick HL: Phosphorylation of inositol 1,4,5-trisphosphate receptors by protein kinase B/Akt inhibits Ca2+ release and apoptosis. Proc Natl Acad Sci USA 2008;105:2427-2432.

31 Nagaleekar VK, Diehl SA, Juncadella I, Charland C, Muthusamy N, Eaton S, Haynes L, Garrett-Sinha LA, Anguita J, Rincon M: IP3 receptor-mediated $\mathrm{Ca}^{2+}$ release in naive CD4 T cells dictates their cytokine program. J Immunol 2008;181:8315-8322.

-32 Lavenburg KR, Ivey J, Hsu T, Muise-Helmericks RC: Coordinated functions of Akt/PKB and ETS1 in tubule formation. FASEB J 2003;17:2278-2280.

33 Sioud M: Promises and challenges in developing RNAi as a research tool and therapy. Methods Mol Biol 2011;703:173-187.

-34 Martin VA, Wang WH, Lipchik AM, Parker LL, He Y, Zhang S, Zhang ZY, Geahlen RL: Akt2 inhibits the activation of NFAT in lymphocytes by modulating calcium release from intracellular stores. Cell Signal 2012;24:1064-1073.

-35 Khan MT, Wagner L, Yule DI, Bhanumathy C, Joseph SK: Akt kinase phosphorylation of inositol 1,4,5-trisphosphate receptors. J Biol Chem 2006;281:3731-3737.

-36 Rong YP, Bultynck G, Aromolaran AS, Zhong F, Parys JB, De Smedt H, Mignery GA, Roderick HL, Bootman MD, Distelhorst CW: The BH4 domain of Bcl-2 inhibits ER calcium release and apoptosis by binding the regulatory and coupling domain of the IP3 receptor. Proc Natl Acad Sci USA 2009;106:14397-14402.

37 Garrett-Sinha LA: Review of Ets1 structure, function, and roles in immunity. Cell Mol Life Sci 2013;

38 Russell L, Garrett-Sinha LA: Transcription factor Ets-1 in cytokine and chemokine gene regulation. Cytokine 2010;51:217-226.

-39 Tamura T, Hashimoto M, Aruga J, Konishi Y, Nakagawa M, Ohbayashi T, Shimada M, Mikoshiba K: Promoter structure and gene expression of the mouse inositol 1,4,5-trisphosphate receptor type 3 gene. Gene 2001;275:169-176.

40 Ghosh S, Basu M, Roy SS: ETS-1 protein regulates vascular endothelial growth factor-induced matrix metalloproteinase- 9 and matrix metalloproteinase-13 expression in human ovarian carcinoma cell line SKOV-3. J Biol Chem 2012;287:15001-15015.

41 Smith AM, Findlay VJ, Bandurraga SG, Kistner-Griffin E, Spruill LS, Liu A, Golshayan AR, Turner DP: ETS1 transcriptional activity is increased in advanced prostate cancer and promotes the castrate-resistant phenotype. Carcinogenesis 2012;33:572-580.

$\checkmark 42$ Dong L, Jiang CC, Thorne RF, Croft A, Yang F, Liu H, de Bock CE, Hersey P, Zhang XD: Ets-1 mediates upregulation of Mcl-1 downstream of XBP-1 in human melanoma cells upon ER stress. Oncogene 2011;30:3716-3726.

43 Lo IC, Lin TM, Chou LH, Liu SL, Wu LW, Shi GY, Wu HL, Jiang MJ: Ets-1 mediates platelet-derived growth factor-BB-induced thrombomodulin expression in human vascular smooth muscle cells. Cardiovasc Res 2009;81:771-779.

44 Fukao T, Tanabe M, Terauchi Y, Ota T, Matsuda S, Asano T, Kadowaki T, Takeuchi T, Koyasu S: PI3K-mediated negative feedback regulation of IL-12 production in DCs. Nat Immunol 2002;3:875-881.

45 Fukao T, Koyasu S: PI3K and negative regulation of TLR signaling. Trends Immunol 2003;24:358-363. 